\title{
Globalization: Mere Hiccup, Major Convulsion or Mega Transformation?
}

Nikhilesh Dholakia

University of Rhode Island

Deniz Atik

University of Texas Rio Grande Valley

Follow this and additional works at: https://digitalcommons.uri.edu/mgdr

Part of the Anthropology Commons, Communication Commons, Economics Commons, Geography Commons, Marketing Commons, Other Business Commons, Political Science Commons, and the Sociology Commons

\section{Recommended Citation}

Dholakia, Nikhilesh and Atik, Deniz (2017) "Globalization: Mere Hiccup, Major Convulsion or Mega Transformation?," Markets, Globalization \& Development Review. Vol. 2: No. 3, Article 1.

DOI: 10.23860/MGDR-2017-02-03-01

Available at: https://digitalcommons.uri.edu/mgdr/vol2/iss3/1

This Editorial is brought to you for free and open access by DigitalCommons@URI. It has been accepted for inclusion in Markets, Globalization \& Development Review by an authorized editor of DigitalCommons@URI. For more information, please contact digitalcommons-group@uri.edu. 
Globalization: Mere Hiccup, Major Convulsion or Mega Transformation?

\section{Markets, Globalization \& Development Review}
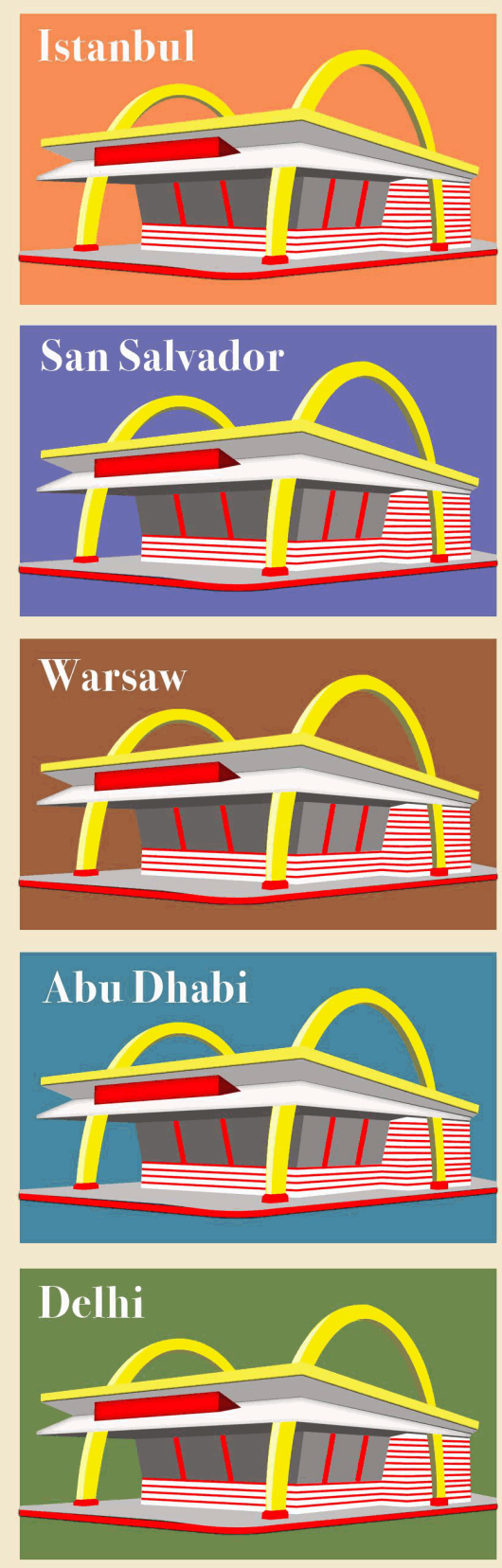
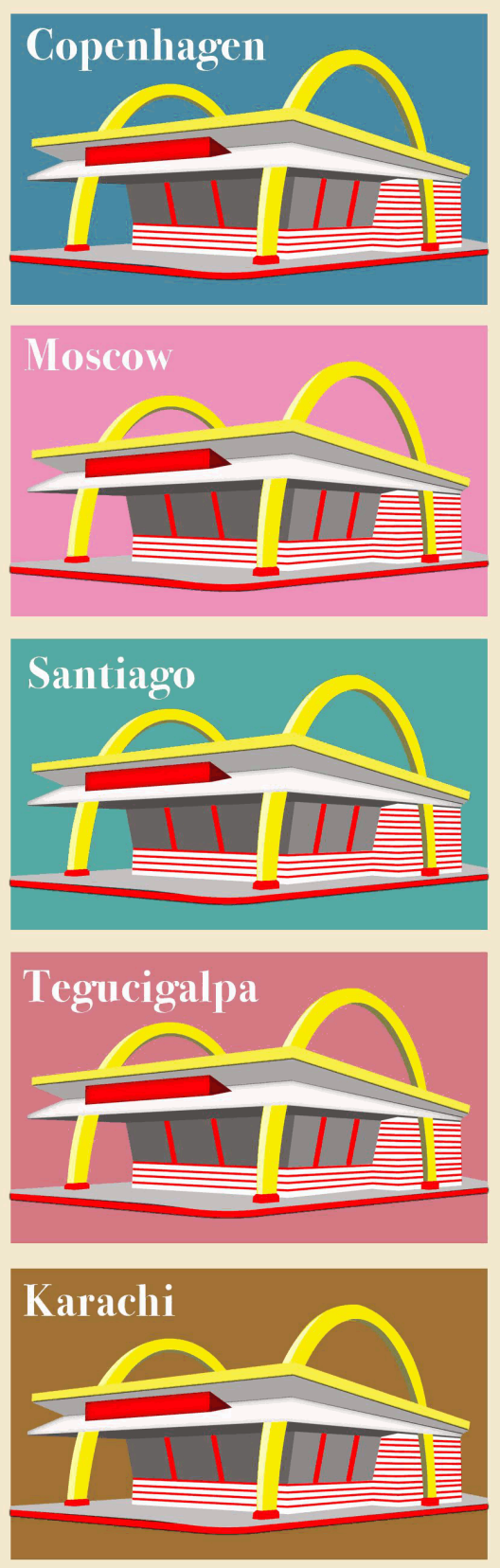
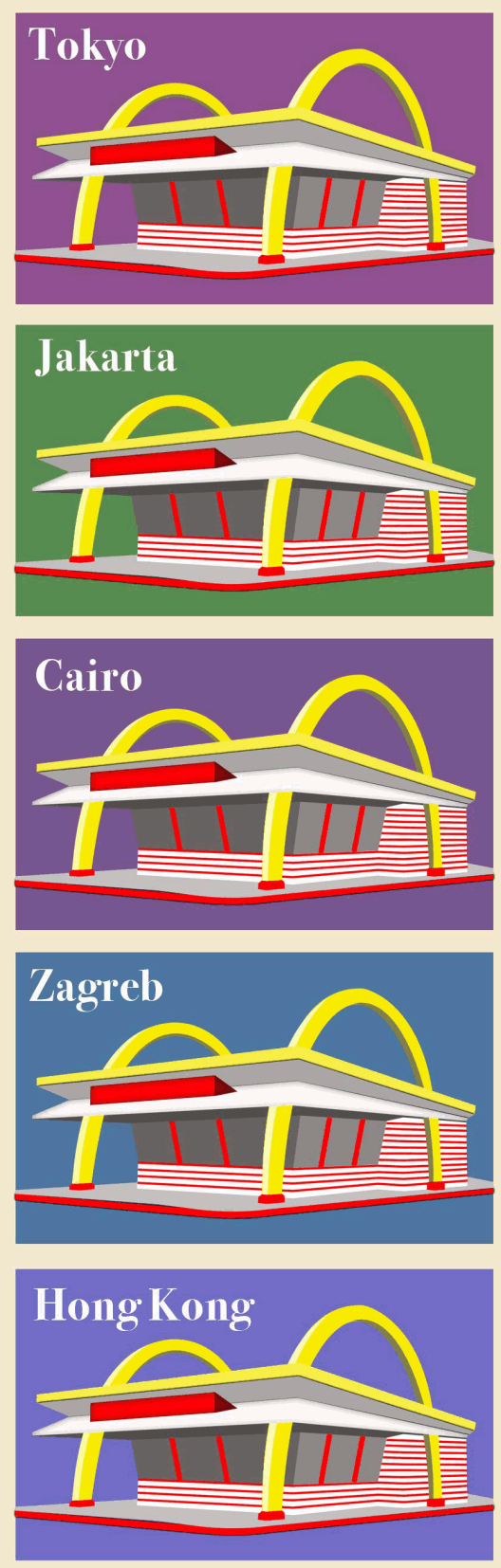

This editorial is available in Markets, Globalization \& Development Review: https://digitalcommons.uri.edu/mgdr/ vol2/iss $3 / 1$ 


\section{Globalization: Mere Hiccup, Major Convulsion or Mega Transformation?}

\section{Introduction}

Globalization - in economic and cultural terms - has been the fuel for the growth of markets for goods and services as well as for the rapid socioeconomic ascent of several countries, often from conditions of deprivation and poverty to middle-class and even affluent status. Globalization also, of course, has left a couple of billion global citizens in desperate straits, in the poorer nation; and, in the advanced nations, globalization has sometimes pulled several million people away from comfortable middle class standards they had achieved.

When the Brexit vote and the Trump elections of 2016 shook up the global political economy, a key question that emerged was simply this: "Whither globalization?"

In principle, the alternative paths to the future could lead to various possible futures:

- A state of near-autarky, each nation for itself, with trade and investment flows on a strictly quid-pro-quo basis; or

- A world of constant trade wars and cross-nation political-economic strife, a kind of neo-mercantilism; or

- Perhaps a situation of ho-hum and yawning relook at the world, where there could be a lot of hot anti-trade rhetoric but not much practical change in the patterns of international trade and investment.

In political terms, major changes did emanate from the UK as well as from the USA. The former is embroiled in a contentious negotiation process with the EU about the United Kingdom exiting the union. USA, after the Trump victory, abrogated or threatened major trade treaties, withdrew from the Paris Climate Accord, and pulled away from several international and global arrangements that deal with vexing issues like poverty, education and migration. In both cases, the political intent of stepping away from galloping globalization has led to significant policy changes.

Overall, however, the debilitating body blow to globalization that many expected has not occurred - at least not until the publication of this MGDR issue. Indeed, major attempts are underway to fill the partial political-economic vacuum created by retreating America and Britain. China in particular is pushing hard to position itself as the new pro- 
globalization central force; and France and Germany are in similar quests for global political influence.

For MGDR, globalization is in the journal's title, and in the very DNA of the journal and the parent organization ISMD. Reinforcing our initial call in the inaugural issue of MGDR for rebalancing the capitaldriven, market-oriented globalization boat towards social justice and equality (Dholakia and Atik 2016), in this special issue, we explore and investigate globalization, in the post-Brexit and Trump triumph world.

Over the past decades, the growing inequalities and affiliated economic, political, cultural and environmental failures and disasters unfolded towards a new global condition, which expresses itself in wide ranging regional and transnational conflicts, frequently accompanied by large-scale death, disease, torture, pillage, rape and migration. In recent years, local reactionary movements from completely opposite ends of the spectrum, both from the radical left and the scary radical right, are gaining ground, even in countries that are supposed to be on the benefiting side of the globalization spectrum.

The Brexit vote in UK and the right-wing populist Trump triumph in the USA can be interpreted as a vote of no confidence for the future of globalization as we know it. Our aim in this issue is to broaden the scope of discussion by asking: Is this a mere hiccup, a major convulsion, or a mega transformation in the political, economic and social affairs of the contemporary world? The articles, commentaries and reviews in this special issue address some facets of this question that MGDR editors posed in communications with several people. In the next section, we summarize how the contributors shed light on facets of the "hiccup-ormore" query. As we see it, globalization does not appear to be - as of now - in severe retreat; but it does seem to be undergoing significant changes. For this journal, the position of the editors and most readers is neither proglobalization nor anti-globalization. Rather, our interest is in the trajectories of globalization, and in contemplating about and intervening towards alternative and sustainable routes and forms of international and intercultural exchange that promise prosperity for everyone involved. In short, our ultimate interest is in the third term in the title of the journal, i.e., in development.

\section{Commentaries and Articles in this Issue}

Belk (2017) introduces collective narcissism as an appealing explanation of the shift to the right, isolationism, the retreat from globalism, and resistance to international refugees in the West. The author describes collective narcissism as an emotional belief that the nation's greatness is 
being threatened by others (see Khandwalla 2017, also in this issue, for much more on the notion of 'greatness'). In the case of Brexit and Trump, this can be illustrated as "the loss of control at the hands of others such as the European Union, China, Mexico, Islam; and both legal and illegal immigrants (p.1)." Belk also argues that besides this political effect at the collective level, individual narcissism among leaders with the feelings of privilege and entitlement can facilitate conspicuous consumption. The author suggests that if this protectionist shift by narcissistic leaders such as Trump, Putin, and Erdogan were a globalization hiccup, there still remains the question of how long this will last.

In his thought-provoking piece, Firat (2017) expands his discussion on the dynamics of the local and the global previously published in MGDR (FIrat 2016). He introduces the readers to a new perspective regarding the beginnings of globalization. Contrary to the commonly accepted view, he suggests that human beings were global (i.e., migratory and without borders) to begin with and then localized as they started to reduce hunting and gathering and got into agriculture and animal husbandry. During the hunting and gathering times when human populations survived through migrating, as the author points out, they exchanged genes, tools, cultures - in effect, they were already globalizing. In the second part of his commentary, Firat analyzes the contemporary conditions of globalization. $\mathrm{He}$ suggests that today we are experiencing a market centered iconographic culture. "The globalization we are experiencing, therefore, is one where market capitalism is managed by a combination of original and budding capitalists who serve the corporations, the central institution of the market capitalist order (p.6)." He points to the possibility of a rich, inclusive symbolic culture to succeed the neoliberal, branded, iconographic culture.

Madra (2017) problematizes the forced choice between neoliberalism and populism, which is argued to be imposed by the post2008 (the post 'Great Recession') crash phase. From a political-economic perspective, the author sees neoliberalism versus populism not as contradicting ideological formulations, but (borrowing the term of Frederic Jameson) as 'antinomies' - static, despotic statements that resist dialecticization, mediation and transformation, which actually remain and fester as "the symptoms of underlying contradictions". To open up the discussion to new threads in lieu of this forced choice, the author interrogates and reorganizes the terms of such antinomies in new combinations. Madra's deconstruction of the association of neoliberalism with internationalism and globalization, as well as the association of populism with nationalism and anti-imperialism, reveals that how 
reactionary forms of populist nationalisms are in fact enabled by neoliberal political incentives and the globalization of finance capital. The author illustrates this with examples from Trump's and Erdoğan's politics and BRIC nations' economies. Finally, he points to the possibilities of the politics of de-growth for offering a radical, trans-local alternative to reactionary populisms.

In the globalization tussles, especially of the post-Brexit and Trump era, one set of terms that comes up with some regularity is concerning 'great' and 'greatness'. Some political leaders (especially in the advanced nations) direct populist anger toward 'loss of greatness', due to unfair patterns of globalization, while others (mainly in the emerging economies) make strong promises of unfolding and glorious greatness ahead, ironically, aided by globalization. Pradip Khandwalla (2017) turns our attention to the core issue of 'civilizational greatness'. His quest is to understand what makes a civilization great. While his focus in on India, he casts a wide global net to understand the patterns and processes that have, at one time or another, led to a nation or civilization ascending to the pedestal of 'greatness'. The overview of the multiple pathways to civilizational greatness in this paper is, in itself, a great contribution. It illuminates - for MGDR readers specifically and for the intellectually curious world generally - ways in which civilizational greatness has been achieved, and can be achieved by those seeking it or recaptured by those pining to 'regain' it. At the end of the paper, a detailed case study of Sweden is presented, showing that - in a quiet and dignified way - the country employed almost all the items in the toolkit for civilizational greatness. What Khandwalla offers is a calming antidote to both, the populist anger for loss of greatness (in USA, UK, France) and the brash boasting and racing to greatness (in China, India, and similar emerging economies).

\section{Reviews in this Issue}

This special issue of MGDR also has one book review and one film review. From a critical perspective, Rodner (2017) reviews Breakout Nations - In Pursuit of the Next Economic Miracles by Ruchir Sharma (2013) and provides an attentive overview of the book that focuses on the current socioeconomic, political, and cultural conditions of the emerging markets. Rodner also delivers rich insights about the content of the book summarizing different sections related to BRICS nations (Brazil, Russia, India, China, South Africa), Mexico, Turkey, South Korea and finally the 'Fourth World' (in other words, frontier nations) that encompasses virtually every country that is not yet considered as an emerging market. According 
to Rodner, a key take away from the book is that no two emerging or frontier nations are alike and therefore each case should be assessed with its own unique socioeconomic, political and geographical features.

Finally, Ozdamar-Ertekin (2017) - in her review of the documentary film, The True Cost by Andrew Morgan (2015) - introduces the bitter truth behind fast fashion, making us question the clothes we wear, the people who make them, and the environmental and societal impacts of the industry. The review outlines the human cost of making textile garments, from the cotton farmers who are exposed to life threatening chemicals to factory workers operating under devastating conditions with extremely low salaries and unfair treatment. From a societal viewpoint, it also shows how this throwaway fashion promotes materialistic values with false promises of happiness. Fast fashion, the second-most-polluting industry in the world after oil industry, creates vast amount of waste with toxic landfills damaging the eco-system. Ozdamar-Ertekin invites the readers of MGDR to question the long-term sustainability of the fast fashion model and presents the pro and con arguments and some of the potential solutions discussed in the documentary film, although the only true solution may seem to be to redesign the fashion industry and the global capitalist system that supports it. For MGDR readers who are interested in this topic, Ozdamar-Ertekin also published a comprehensive research article in MGDR that outlines the conflicting perspectives on speed of the fast fashion system and its devastating social and environmental consequences (Ozdamar-Ertekin 2016).

\section{Invitation for more Works on Globalization}

There were some potential authors who had expressed interest in writing commentaries or articles, or reviews, on the contested aspects of globalization that this MGDR issue deals with - but the prevalent circumstances prevented such contributions reaching us in time for our review process. We may be able to get some of these contributions in future issues. Also, again given the centrality of the term 'globalization' to this journal, we invite others interested authors to contact us with possible topics or submit relevant papers for review. In the issues to come, we will keep exploring globalization - sometimes with a strong national focus, and at other times in more general terms. 


\section{References}

Belk, Russell (2017), "Collective Narcissism, Anti-Globalism, Brexit, Trump, and the Chinese Juggernaut," Markets, Globalization \& Development Review, 2 (3), Article 2. DOI: https://doi.org/10.23860/MGDR-2017-02-03-02

Dholakia, Nikhilesh and Deniz Atik (2016), "Markets, Globalization, Development: Charting the Intersections of Three Multipolar Concepts," Markets, Globalization \& Development Review, 1 (1), Article 1. https://doi.org/10.23860/MGDR-2016-01-01-01

Fırat, A. Fuat (2017), "Orbits of Contemporary Globalization"' Markets, Globalization \& Development Review, 2 (3), Article 3. DOI: https://doi.org/10.23860/MGDR-2017-02-03-03

Firat, A. Fuat (2016), "The Dynamics of the Local and the Global: Implications for Marketing and Development," Markets, Globalization \& Development Review, 1 (1), Article 4. https://doi.org/10.23860/MGDR-2016-01-01-04

Khandwalla, Pradip N. (2017), "Globalization Tumult and Civilizational Greatness," Markets, Globalization \& Development Review, 2 (3), Article 5. DOI: https://doi.org/10.23860/MGDR-2017-02-03-05

Madra, Yahya M. (2017), "Antinomies of Globalization," Markets, Globalization \& Development Review, 2 (3), Article 4. DOI: https://doi.org/10.23860/MGDR-2017-02-03-04

Ozdamar-Ertekin, Zeynep (2017), "Andrew Morgan, The True Cost (2015): The Bitter Truth behind Fast Fashion," Markets, Globalization \& Development Review, 2 (3), Article 7. DOI: https://doi.org/10.23860/MGDR-2017-02-03-07

Ozdamar-Ertekin, Zeynep (2016), "Conflicting Perspectives on Speed: Dynamics and Consequences of the Fast Fashion System", Markets, Globalization \& Development Review, 1 (1), Article 6. https://doi.org/10.23860/MGDR-2016-01-01-06

Rodner, Victoria L. (2017), "Ruchir Sharma, Breakout Nations (2013)," Markets, Globalization \& Development Review, 2 (3), Article 6. DOI: https://doi.org/10.23860/MGDR-2017-02-03-06

Sharma, Ruchir (2013), Breakout Nations - In Pursuit of the Next Economic Miracles, New York, NY: W.W. Norton \& Company. 
Dholakia and Atik: Globalization: Minor or Mega Change?

The True Cost (2015), directed by Andrew Morgan, produced by Untold Creative LLC. 